\title{
A Comparative Study on Daylight Performance of Konya Mosques Built in Anatolian Seljuk and Ottoman Period
}

\author{
Ayşıl Coşkuner Pamuk ${ }^{1}$, İbrahim Agah Taştemir ${ }^{2} \odot$, Ümit Arpacıoğlu ${ }^{3} \odot$ \\ ${ }^{1}$ Res. Asst., Department of Architecture, Istanbul Sabahattin Zaim University, Istanbul, Turkey. (Principal contact for editorial \\ correspondence), Email: aysil.pamuk@izu.edu.tr \\ ${ }^{2}$ Res. Asst., Department of Interior Architecture and Environmental Design, Istanbul Sabahattin Zaim University, Istanbul, \\ Turkey. (Principal contact for editorial correspondence), Email: ibrahim.tastemir@izu.edu.tr \\ 3 Assoc. Prof. Dr., Faculty of Architecture, Mimar Sinan Fine Arts University, Istanbul, Turkey. Email: \\ umit.arpacioglu@msgsu.edu.tr
}

\begin{abstract} Purpose

Daylight control and energy efficiency in architectural design is accepted as one of the main inputs of sustainable architecture. In the present study, we investigate the importance of light factor and daylighting design criterias as the construction technique of mosques improves by adhering to different periods.

\section{Design/Methodology/Approach}

Interior space designs of three different Mosques are displayed via plan sketches, therefore every mosque is evaluated particularly in summer term periods when users pray inside mosques in particular day and hour periods. In-situ evaluation results are tested by a luxmeter and comfort device. Each mosques' technical plans are modelled in 3D programme. Measures are evaluated only when there is natural light inside.
\end{abstract}

\section{Findings}

The major design criterias and construction techniques stated in this study will give inspiration to builders to design praying halls which have perfect lighting performance with sacred sense of worshipping activities with full of serenity and concentration.

\section{Research Limitations/Implications}

Short-term and very limited in situ measurements were taken in Konya mosques due to pandemic precautions. Also evolved computational datas of DB programme are the main limitation of this study.

\section{Originality/Value}

This study is the first to emphasise the importance and development of daylight in places of worship in the center of Konya, depending on the order of architectural design according to different periods. There are very few studies that examine the effect of daylight in worship places and its impact on construction and design. Daylighting in historic Islamic architecture can be further studied via simulation programme.

Keywords: Daylight, traditional mosque design, interior space, daylight comfort 


\section{INTRODUCTION}

One of the basic human need is living in comfort. Daylight is one of the important factors that affect the comfortable indoor environment. In buildings, the most important building component that creates the balance between natural environment and space is the building envelope. Daylight is used in architectural design to provide internal space needed to carry out activities in accordance with a space. The light in architecture is responsible for improving living space. Daylighting also provides consistency of creating the inner atmosphere, effecting texture, colour, and dynamic sense of the space which is related to the dynamical changing between day and night (Yahya,2014).

Daylight affects the design of buildings destined to house religious activities as ancient cultures. Ancient cultures used daylight to try incorporataion in the design of their most representative buildings. Ancient Egyptians used daylight in orientation, sanctuary and processional paths, designed according to movement of the sunlight. Ancient Greeks used these in their templates to orientate towards the east to relate directly to the first light of the day. The Romans, the first to consciously design interior space, used daylight in their templates to enhance and articulate space. (Antonakaki, 2007) On religion and cultural side, throughout history, light's symbolic role has been related to sacred, religious and cosmologic beliefs. Light was given great significance in the Jewish , Christianity and Islamic beliefs ( Arel, etc.,2017).

Early architecture and building structure technology use local environmental factors influenced the shaping of building faces and restricted the role of the building envelope for secure and protect the indoor environment and occupants. Early architecture primary task to build was keeping building structure to standing and providing indoor climate for health. In hot and cold climates early architecture buildings openings was limited because of climatic conditions (Figure 1), (Lechner N. 2001), (Stein, 2000).
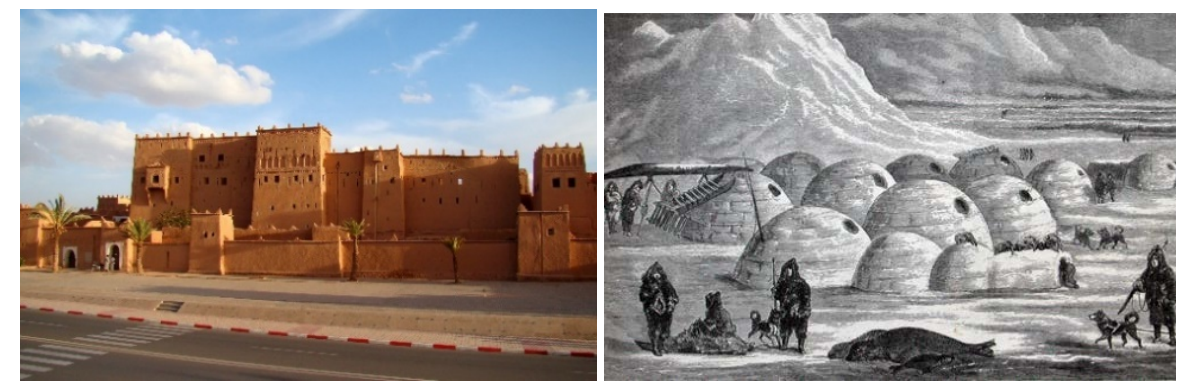

a.

b.

Structural technology and development of architecture brings to arch and the dome, and they create potential for larger openings that can admit to advancing use of daylighting strategies. The architectural form of buildings, placement of windows, and location of rooms lead by the availability of daylight as the primary source of illumination. Especially in
Figure 1. Early architecture examples from hot and cold climates.

a: Traditional Kasbahs, Morocco

b: Eskimo, Inuit Houses

(Bjørn, 2011;

Philip J.H., 2016) 
A Comparative Study on Daylight Performance of Konya Mosques Built in Anatolian Seljuk and Ottoman Period

monumental architecture like religious buildings, daylight is used for not just providing indoor climate, also as visual comfort for occupants. (Phillips, 2004), (Chepchumba,2013)

In Ancient Rome period, the advancements in openings were squareheaded or circular. Especially the first application of glazing allowed daylighting. Ancient Roman building skylights and clerestories were larger and provided more light into deep interiors. (Figure 2) In Byzantine period, buildings were centralized around a primary dome surrounded by secondary spaces covered with half domes intersecting below the main dome. Daylight admitted through many small stainedglass windows grouped together piercing the base of the dome (Chepchumba,2013).

Figure 2. Ancient Rome and Byzantium Construction Development effect of daylighting

a: Pantheon, Rome

b: Hagia Sophia, Istanbul (Deutsche Welle, 2017;

Burney, 2016).
Figure 3. Early Islamic Architecture and usage of daylighting

a: Umayyad Mosque,

Damascus

b) Alhambra Palace, Granada

(Horsey, 2019; Greatest Paka Photography, 2012).

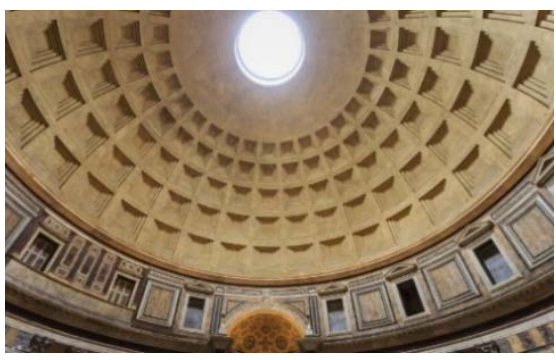

a.

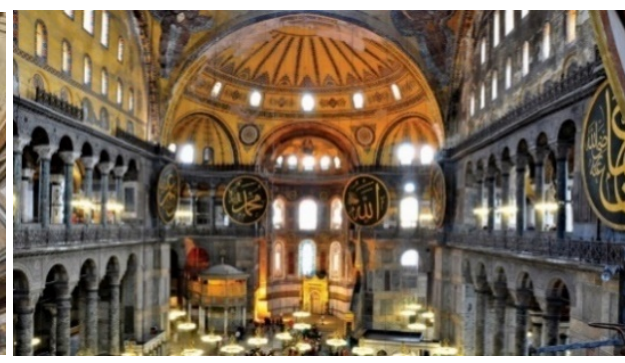

b.

In Islamic Architecture, daylight im mosque design is used for providing the creation of an environment where the worshipper can fulfil his religious needs and regular visual comfort objectives. Mosques are the first Islamic building types wherever built. With the spreading of Islam, there had a lot of diversity in mosques architecture affected Byzantine, Persian architectural styles by multiple reasons such as building materials and techniques, elements of environment and culture (Figure $3)$.

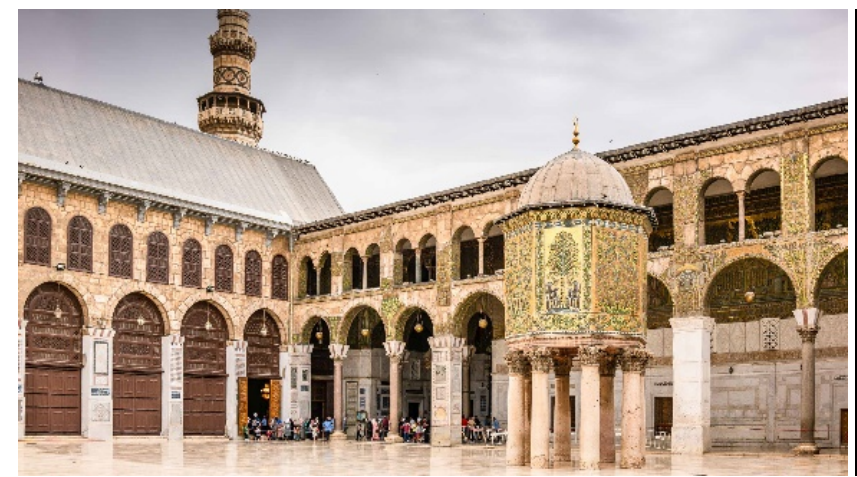

a.

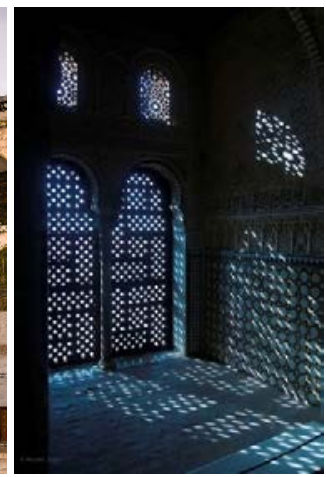

b.
After the $11^{\text {th }}$ century in Islamic architecture, with the influence of the Anatolian Seljuks, mosques were built in a unique style which was fed from different cultures. This architectural style continued to develop with Ottomans. Ottoman and Seljuks Islamic architectural style and construction system is seen in a wide geography from Central Asia to 
Europe from $11^{\text {th }}$ Century to $20^{\text {th }}$ century. Anatolian Seljuks built many monumental buildings in Anatolia with the effect of local cultural identity and Asian Turkish cultural identity. Subsequently Anatolian Seljuks and Ottomans continued to develop this architectural design and construction system. Especially in the $16^{\text {th }}$ century, the age of architect Sinan period is an important development point in Ottoman and Islamic architecture.

The architect Sinan designs, and his construction system is still considered one of the architects of Ottoman's Architecture. One of the most important properties of Sinan's designs was the concern in employing physical environmental factors like ventilation, sound and especially light in the interior space, which derives from the structural development. Sinan construction system brought the covering system on to columns and piers, an important potion of which was moved to the exterior parts for supply the unification of the space and increase interior light. Sinan Period and after, Ottoman Mosque architecture continued to grab light intentionally, which yielded a bright and spacious interior (Figure 4) (Yahya, 2014).

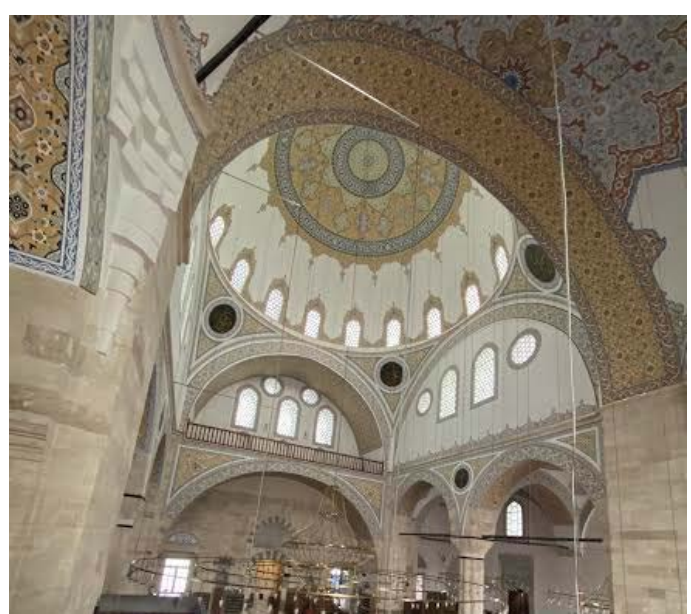

a.

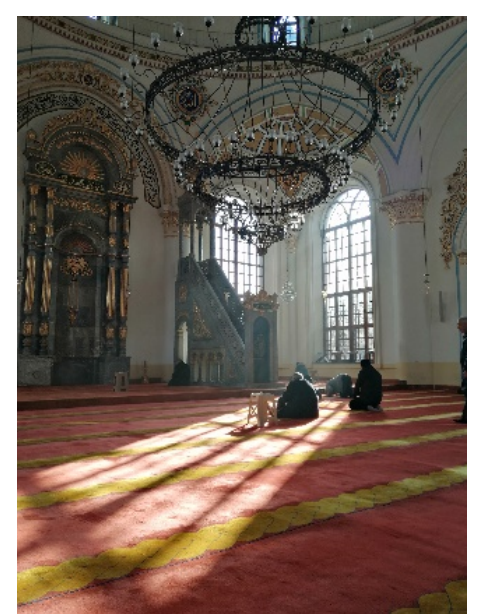

b.
The aim of this study is to identify the lighting performance of mosques which were constructed in Konya region within different periods. All mosques were constructed in Anatolian Seljuk, Ottoman Classical Architecture and Ottoman Late Baroque Periods.

This paper consists of five consecutive parts. First part includes the case study description. It starts with the methodology of study including the daylighting analysis. In second part, methods is described in which different design strategies and construction techniques are defined. In the third part of study, daylighting analysis comparative results are explained and discussed with graphics method. The fourth and final part concludes the analysis with graphical results and give advice and suggestions.
Figure 4. Classical and Late Baroque Ottoman Architecture Period usage of daylighting

a: Sultan Selim Mosque, Konya

b: Aziziye Mosque, Konya

(Photographs by the authors, 2019). 


\section{LITERATURE REVIEW}

There are very few studies that examine the effect of daylight in mosque design. Arab et al.,2013 measure lighting performance of single pendentive dome type and pyramid roof type in Islamique mosque design built during the Ottoman Empire in Istanbul, Turkey and Mostar, Bosnia Herzegovina. The authors prove the fact that having excellent illuminance level distributed at all the locations is one of the crucial reasons why the mosques with pedentive dome roof cover are built by Ottoman master builders. The study is simulated during winter solstice and analysis are measured using Autodesk software known as 3D Studio Max Design 2011 programme. As a different type of study Mazloomi.,2010 examines the importance of Window to Wall Ratio [WWR] seeks its influence on daylight factor in southern part of Malaysia by modeling in Ecotect V5.60. These two studies jointly investigate the effect of the dome form in mosque function on daylight analysis. Another study belongs to Antonakaki., 2007 and two religious buildings belonging to two different religions but found at the same time are discussed in terms of daylight. The study compares the relation between the spatial structure and the lighting in Early Ottoman mosques and Byzantine churches. There is no information on which modeling program is used regarding lighting levels and daylight results. Another research that evaluates the daylight analysis in mosque architecture without using any simulation program belongs to Shahani, 2018. This research analyze how daylight pervades the sequential spaces of Sheikh Lotfollah Mosque, Isfahan, Iran, one of the most well-known mosques, during the day. The spaces of the mosque present several appearances of daylight, controlled during different time intervals. Photographs of the spaces taken with the help of a camera depict the different daylight penetrations from outside to inside the mosque, categorized into different episodes. Another method of daylight measurement in mosques is researched and used by El-Darwish et al.,2016. The study emphasize that there is very few theories regulating mosque design. Climate-based simulations are done in Rhino as a modeling platform with the DIVA lighting analysis plug-in to present a general overview of the role of fenestration on daylight performance in order to examine the close relationship between fenestration and day-light autonomy. Aljofi,2018 conducts a pilot field investigation of daylight performance through domes for more than 10 domes mosques in the Eastern province of Saudi Arabia. In situ measurements by a lightmeter is evalutaed and a physical model is used for the experiment. Very parallel to our research Kammoun et al.,2016 proves that the daylight distribution in the studied mosque is directly related to the shape of mosques and particularly, the courtyard shape, the presence of galleries, the architectural devices used to favor the introduction of the natural light and the naves orientation by using Radiance software Ecotect Programme. Another research whith similar pupose to our study belongs to Hareri et al., 2020. The study analyses the physical characteristics of two Mosques located in Jeddah city, Saudi Arabia, built at different time 
periods. The analysis focuses on investigating different design techniques used to lighten the interior space, and how this can be related to the identity of the mosques. In addition, it explores how the orientation of mosques, determined by the Qibla direction, has impacted the indoor lighting quality. Unlike our study, in Hareri et al., 2020; illuminance level comparisons were made only through observation.

\section{CASE STUDY DESCRIPTION}

A selected sample of three mosques built in different centuries was studied on a simulation tool to compare illuminance levels.

\section{Inner Space Description of Selected Mosques}

The indoor lighting performance is evaluated using illuminance level as the measurable scale. This illuminance level is measured in lux per metre square (lux/m2), which means the amount of luminance (lux) affected on a $1 \times 1 \mathrm{~m}$ surface area. By referring to this measurement, this study can determine the indoor lighting performance inside the mosque (Runsheng ,2009). Building design using daylight system is considered as having excellent passive lighting design. (Arab,2012) Daylight is lighting, obtained from indirect sunlight source which provides the best source which matches with human visual response. The windows above the dome allows sunlit penetration. The amount of daylight penetration into a building through sunlit area from windows and door openings provides dual functions not only of admitting natural light into the indoor area but also allowing the occupants to have visual contact with the outdoor environment.

\section{Tahir and Zühre Mosque}

The first mosque chosen for the study was Tahir and Zühre Mosque (Fig. 5) located in Meram neighbourhood. The mosque was constructed in $13^{\text {th }}$ century by Sahip Ata who is one of the characters who had the longest political career in Anatolian Seljuk period. Sahip Ata, who had all the important assignments during his governmental job for approximately forty years, is the patronage of some of the most important magnificent buildings. (Yavaş, 2008) It was designed as Classic Seljuk architecture style. The mosque is located on north-eastern side of Konya. The prayers' area located on southwestern side of the mosque is a square shaped with $6 \mathrm{~m} * 6 \mathrm{~m}$ dimensions. The square shaped zone is covered by a single dome. The main element of the mosque represents a void with double volume space surmounted under a pendentive dome as the roof cover. It was constructed by 'Türk Üçgeni" a characteristic squinch type. There are no windows at the bottom of the dome. There are three windows on the northern side, one on the western side and two on the eastern wall. There are no clerestory windows. The dome measurement based on the building plan and section has $2.7 \mathrm{~m}$ in radius and the square wall height is $5 \mathrm{~m}$. The building height (dome with square wall) is $6.70 \mathrm{~m}$. 
Figure 5. Tahir Zuhre Mosque Indoor Photo and Plan

(Photographs by the authors, 2019).

Figure 6. Sultan Selim Mosque Indoor Photo and Plan (Photographs by the authors, 2019).
A Comparative Study on Daylight Performance of Konya Mosques Built in Anatolian Seljuk and Ottoman Period

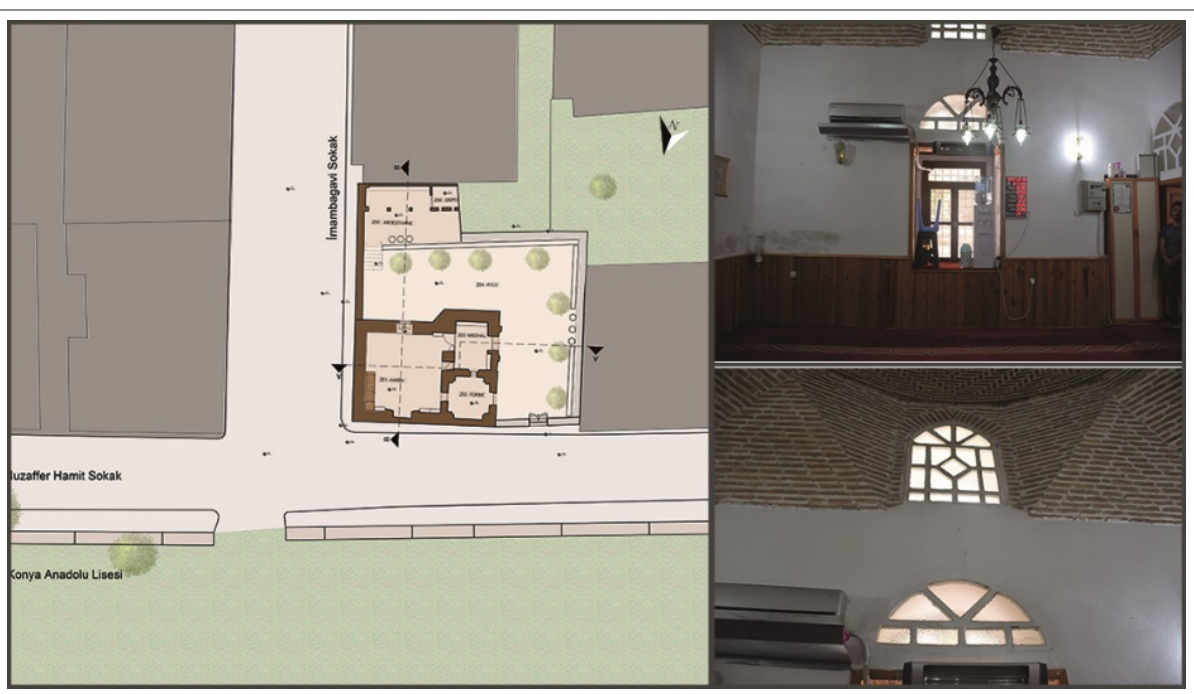

\section{Sultan Selim Mosque}

The second mosque (Fig. 6) selected for the purpose of this study is Sultan Selim mosque which is a $16^{\text {th }}$ century Ottoman Mosque constructed in Classical Ottoman architectural style. It is located in Konya's Karapınar neighbourhood $97 \mathrm{~km}$ away from Central Konya and near Mevlana mausoleum. The mosque's construction began in 1558 and was not renovated till $18^{\text {th }}$ century. The almshouse called 'imarethane" located on the western side of the mosque was constructed as additional building to the mosque when Selim II was on the throne. The mosque is located on southern side of Konya.

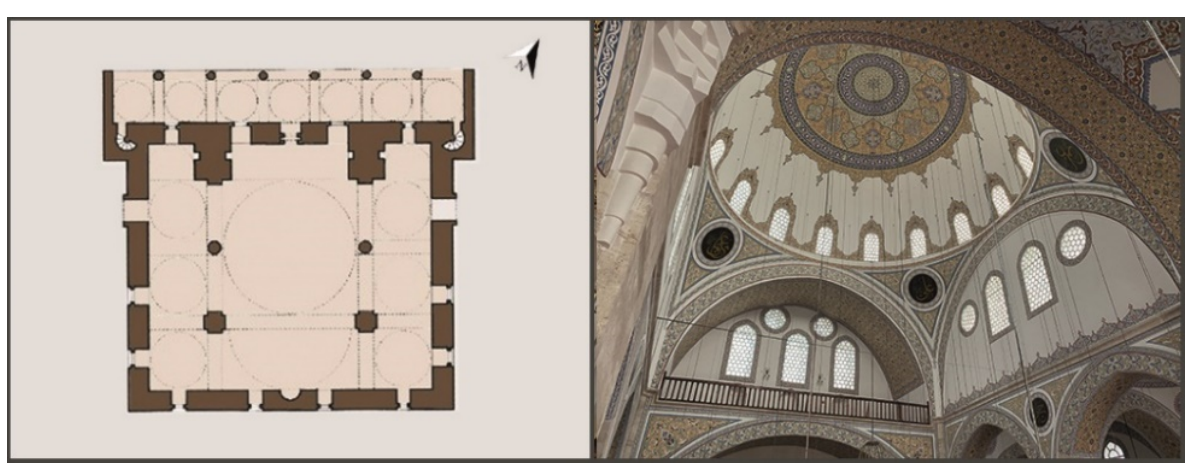

The prayers' area located on the south-eastern side of the mosque is square shaped with $25 \mathrm{~m} * 25 \mathrm{~m}$ dimensions. The square shaped zone is covered by a single dome and semi-dome roof covers, This square form is developed by half domes attached to main square, known as "Riwaq". There are two major and two circular shaped windows on every side except the southern bottom of the dome. There are seven windows on northern part, four on the western side and three on the eastern wall. There are eight clerestory windows. The dome measurement based on the building plan and section has $9 \mathrm{~m}$ in radius and the square wall height is $12 \mathrm{~m}$. 


\section{Aziziye Mosque}

The third (Fig. 7) selected purpose of this study is Aziziye Mosque which is a $19^{\prime}$ th century Late Ottoman building constructed in Baroque architectural style. It is located in Konya's Karatay neighbourhood in Central Konya and near Bezirganlar Çarşısı. It was exposed to fire in 1867 and reconstructed in1872. The mosque is located in southwestern edge of central Konya. The prayers' area located on the western side of the mosque is a square shape with $20 \mathrm{~m}^{*} 20 \mathrm{~m}$ dimensions. Fig.7.1) The square shaped zone is covered by a pendentive single dome. Pendentive dome is a construction of 'dome above dome' concept, dome design is supported by four giant arches (Mango, 1976). With simple plan design, this square form is highlighted by square wall construction with a minaret at the west wall adjacent to the building entrance on the north wall. At the bottom of the dome there are eight windows two on each side.

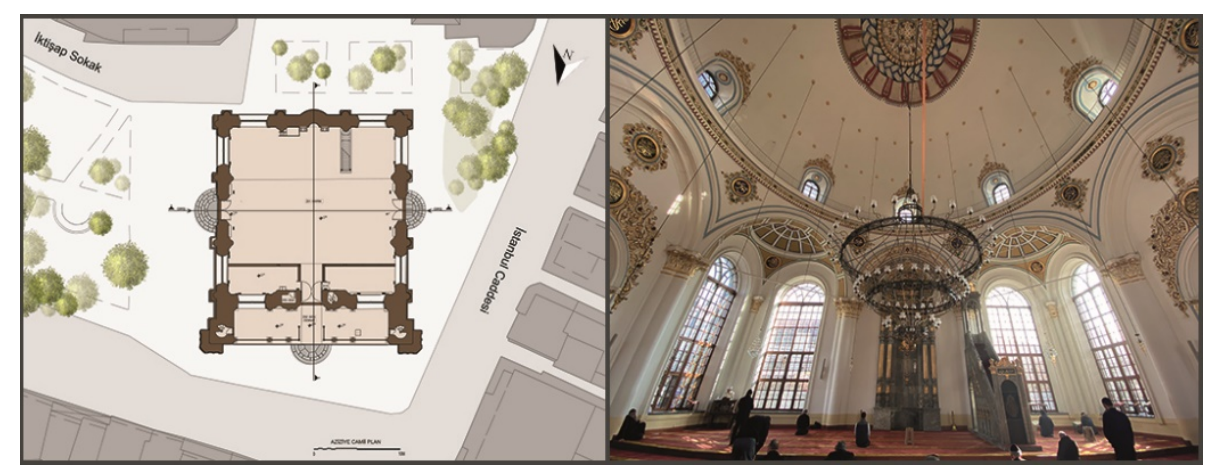

There are two windows on each side of the walls. There are no clerestory windows. The dome measurement based on the building plan and section has $9 \mathrm{~m}$ in radius and the square wall height is $12 \mathrm{~m}$. The building height (dome with square wall) is $19.81 \mathrm{~m}$. The dome is supported by four arches covered as a part of the building stone walls with $1.31 \mathrm{~m}$ in thickness. A mihrab is also an important element of mosques which is a niche area always located at the south wall (2003, Eyice).

\section{RESEARCH METHOD}

The in situ measurements and simulation analysis results are taken into consider. The measurement results tested on $21^{\text {st }}$ December and $8^{\text {th }}$ August have benefited for the verification of simulation results. It is important to consider that the in situ illuminance results match up with the simulation results. This simulation was conducted on $21^{\text {st }}$ of June, $21^{\text {st }}$ of September, 23rd of December and 21 ${ }^{\text {st }}$ of March on the occurrence day of winter, summer and midseason equinox. On $21^{\text {st }}$ of June 2019 when summer solstice occurs, sunrise in Konya is at 5:28am and sunset at 8:16 pm. On $23^{\text {rd }}$ of September when summer solstice occurs, sunrise in Konya is at 6:37am and sunset at 6:48pm. On December,21 when summer solstice occurs, sunrise in Konya is at 8:02am and sunset at 5:34pm. On March,21 when summer solstice occurs, sunrise in Konya is at 6:52am
Figure 7. Aziziye Mosque Indoor Photo and Plan (Photographs by the authors, 2019). 
Figure 8. Hobo comfort analyser devices and D09847 climate analyser device were used in prayer halls on $21^{\text {st }}$ December. (In situ measurements) (Photograps by the authors, 2019).

and sunset at 7:03pm. The simulation dates and hours considered as 09.00,12.00,15.00 and 17.00 depending on sunrise and sunset data's.

This daylight simulation deployed a computer based calculation of the amount of daylight inside the building using Designbuilder programme. Before simulation analysis was conducted, three-dimension drawings of the three mosques were created using AutoCAD software based on one to one scale illustrating exact measurement of the building form with reference to the mosque's two-dimensional AutoCAD plan and section. After that, these three-dimension drawings were redesigned in Designbuilder Programme. A daylight system was created according to dates and hours stated above. The weather data files of Konya in typical year format was created depending on meteorological stations by means of Meteonorm 7 software. In the software, Konya has the only international meteorological station. This station, located in Konya airport region which is approximately $17 \mathrm{~km}$ away from the area where the three mosques are located, was taken as reference in the study. Typical year was created in TMY2 format using the meteorological data between 1991-2010 and then converted to EPW format for DB's use.

Apart from simulations in situ measurements in each prayer area was created by setting points of incidence which specified the illuminance levels at each point. As shown in Figure 8, a lightmeter, Hobo comfort analyser devices and D09847 climate analyser device were used during measurements.
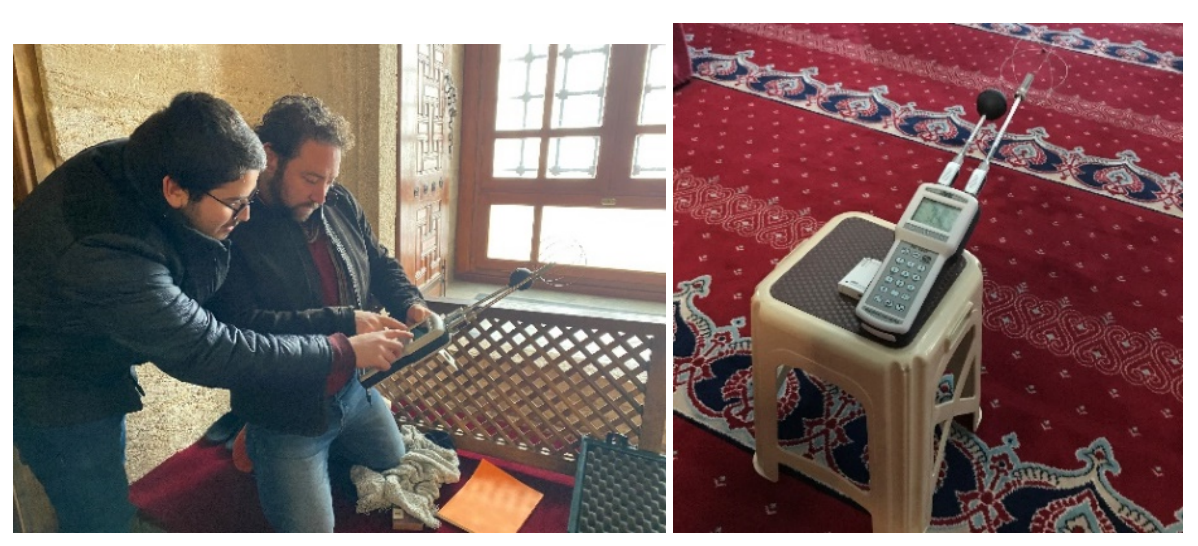

Each subdivision represented a point at which incident illuminance normal to the grid was calculated. The devices were set at human body level for praying at $45 \mathrm{~cm}$ above the ground level of the floor. The results were compared with each other and verified based on the devices and as well on the simulation results. The simulations were done in all three mosques and in situ measurements were done in two selected mosques in $21^{\text {st }}$ December and $8^{\text {th }}$ August. These results allowed us to have comparative analysis of lighting performances among these three mosques which have different construction techniques and built in different centuries. 


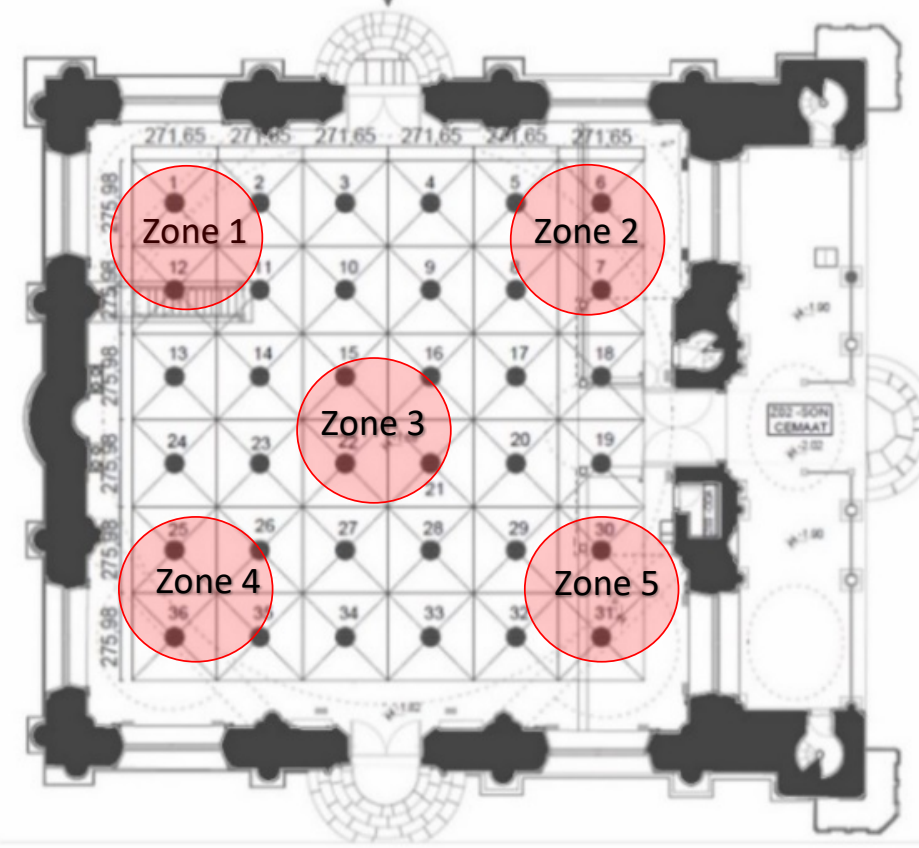

Figure 9. Aziziye Mosque daylight analysis in situ measurements on August 8, 2019

Table 1. Aziziye Mosque daylight illuminance values (in situ measurements including the 5 zones) on August 8,2019

\begin{tabular}{|c|c|c|c|c|c|}
\hline \multicolumn{6}{|c|}{ Konya/ Date: 08.08.2019 02.00-03.00 PM/ Clear Sunny Day } \\
\hline $\begin{array}{l}\text { Selected } \\
\text { Points }\end{array}$ & $\begin{array}{l}\text { Illuminance } \\
\text { Level (lux) }\end{array}$ & $\begin{array}{l}\text { Selected } \\
\text { Points } \\
\end{array}$ & $\begin{array}{l}\text { Illuminance } \\
\text { Level (lux) }\end{array}$ & $\begin{array}{l}\text { Selected } \\
\text { Points } \\
\end{array}$ & $\begin{array}{l}\text { Illuminance } \\
\text { Level (lux) }\end{array}$ \\
\hline 1 & 1100 & 7 & 704 & 13 & 208 \\
\hline 2 & 580 & 8 & 500 & 14 & 275 \\
\hline 3 & 660 & 9 & 414 & 15 & 359 \\
\hline 4 & 415 & 10 & 443 & 16 & 376 \\
\hline 5 & 966 & 11 & 515 & 17 & 340 \\
\hline 6 & 1072 & 12 & 690 & 18 & 350 \\
\hline $\begin{array}{l}\text { Selected } \\
\text { Points } \\
\end{array}$ & $\begin{array}{l}\text { Illuminance } \\
\text { Level (lux) }\end{array}$ & $\begin{array}{l}\text { Selected } \\
\text { Points } \\
\end{array}$ & $\begin{array}{l}\text { Illuminance } \\
\text { Level (lux) }\end{array}$ & $\begin{array}{l}\text { Selected } \\
\text { Points } \\
\end{array}$ & $\begin{array}{l}\text { Illuminance } \\
\text { Level (lux) }\end{array}$ \\
\hline 19 & 248 & 25 & 478 & 31 & 436 \\
\hline 20 & 330 & 26 & 411 & 32 & 353 \\
\hline 21 & 340 & 27 & 345 & 33 & 345 \\
\hline 22 & 330 & 28 & 335 & 34 & 324 \\
\hline 23 & 320 & 29 & 341 & 35 & 445 \\
\hline 24 & 297 & 30 & 371 & 36 & 623 \\
\hline $\begin{array}{l}\text { Average } \\
\text { Illuminance } \\
\text { values for } \\
\text { each zone }\end{array}$ & $\begin{array}{l}\text { Zone1: } \\
1100 \text { lux }\end{array}$ & $\begin{array}{l}\text { Zone 2: } \\
1000 \text { lux }\end{array}$ & $\begin{array}{l}\text { Zone 3: } \\
350 \text { lux }\end{array}$ & $\begin{array}{l}\text { Zone 4: } \\
550 \text { lux }\end{array}$ & $\begin{array}{l}\text { Zone 5: } \\
300 \text { lux }\end{array}$ \\
\hline
\end{tabular}
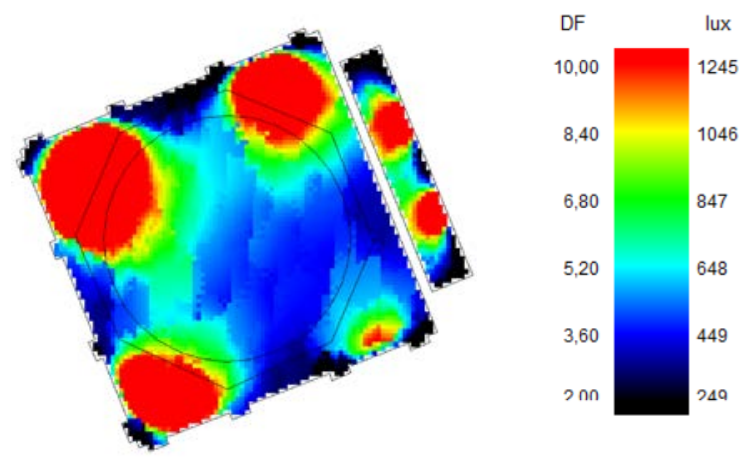

Figure 10. DB Simulation results (Illuminance results) for Aziziye Mosque on August 8,2019 clear sunny day, $14 \mathrm{pm}$ 
Figure 11. Sultan Selim Mosque daylight in situ measurements December 21, 2019
Figure 12. Selected five points for the simulation daylight analysis.

a. Tahir and Zuhre Mosque b. Sultan Selim Mosque c. Aziziye Mosque

A Comparative Study on Daylight Performance of Konya Mosques Built in Anatolian Seljuk and Ottoman Period

As stated in Figure 10 and Table 1, the in-situ measurements described as Zones and the simulation results in DB daylight simulation analysis for Aziziye Mosque on August 8, 2019 overlap. Zone 1 and Zone 2 have better illuminance levels than the other three zones. The lowest illuminance value is at Zone 5 . This order coincides with the simulation results for Aziziye Mosque on August 8, 2019.

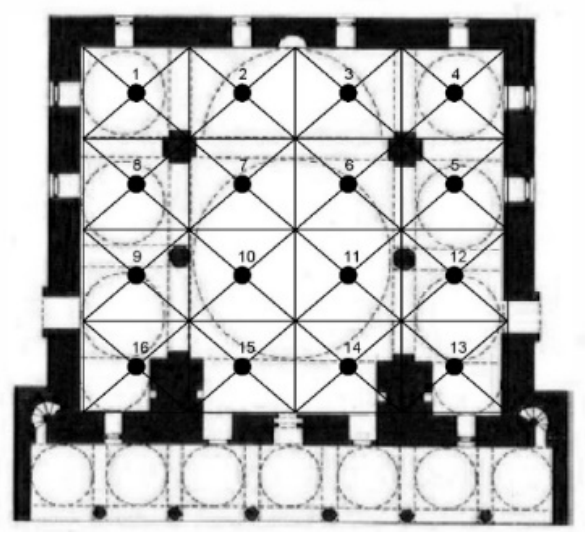

Table 2. Sultan Selim Mosque daylight illuminance values (in situ measurements) on December,21 2019

\begin{tabular}{|l|l|l|l|l|l|}
\hline \multicolumn{2}{|l|}{ Konya Merkez/ 21 December 2019 10.30-11.00/ Very Cloudy Intermediate Day } \\
\hline $\begin{array}{l}\text { Selected } \\
\text { Points }\end{array}$ & $\begin{array}{l}\text { Illuminance } \\
\text { Level (lux) }\end{array}$ & $\begin{array}{l}\text { Selected } \\
\text { Points }\end{array}$ & $\begin{array}{l}\text { Illuminance } \\
\text { Level (lux) }\end{array}$ & $\begin{array}{l}\text { Selected } \\
\text { Points }\end{array}$ & $\begin{array}{l}\text { Illuminance } \\
\text { Level (lux) }\end{array}$ \\
\hline $\mathbf{1}$ & 11,8 & $\mathbf{6}$ & 30 & $\mathbf{1 1}$ & 9,5 \\
\hline $\mathbf{2}$ & 27 & $\mathbf{7}$ & 27 & $\mathbf{1 2}$ & 24 \\
\hline $\mathbf{3}$ & 9 & $\mathbf{8}$ & 100 & $\mathbf{1 3}$ & 3 \\
\hline $\mathbf{4}$ & 21 & $\mathbf{9}$ & 82 & $\mathbf{1 4}$ & 12,6 \\
\hline $\mathbf{5}$ & 25 & $\mathbf{1 0}$ & 28 & $\mathbf{1 5}$ & 23 \\
\hline & & & $\mathbf{1 6}$ & 35 \\
\hline
\end{tabular}

As stated in Figure 11, the in-situ measurements for Sultan Selim mosque on December 21,2019 is compatible with the simulation results stated in Table 6.

For the simulation data's especially five selected points were taken into calculations. These points are located as $1=$ northwest side prayer hall; 2 north eastern side prayer hall; $3=$ southwest side prayer hall; $4=$ southeast side prayer hall; and $5=$ under dome inside the building for each mosque (Figure 12.1,2,3,) The results for each selected points were collected and then converted to tables and line charts.

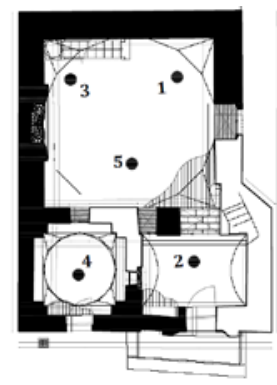

a.

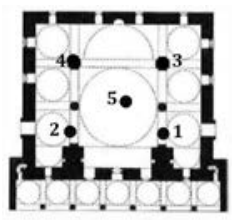

b.

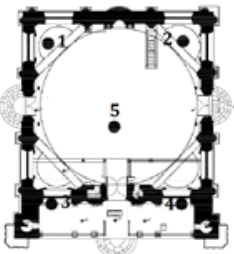

c. 
As simulation methodology, programme daylighting simulations are verified with respective to radiance parameters values in Designbuilder shown in Table 3.

Table 3. Radiance parameters for simulation

\begin{tabular}{|c|c|c|c|c|c|}
\hline $\begin{array}{l}\text { Ambient } \\
\text { Bounces }\end{array}$ & $\begin{array}{l}\text { Ambient } \\
\text { Divisions }\end{array}$ & $\begin{array}{l}\text { Ambient } \\
\text { Sampling }\end{array}$ & $\begin{array}{l}\text { Ambient } \\
\text { Resolution }\end{array}$ & $\begin{array}{l}\text { Ambient } \\
\text { Accuracy }\end{array}$ & $\begin{array}{l}\text { Direct } \\
\text { Treshold }\end{array}$ \\
\hline 7 & 1024 & 20 & 512 & 0,22 & 0 \\
\hline
\end{tabular}

\section{RESULTS and DISCUSSION}

A comparative research between different design features of different mosques are carried out and average illuminance levels for each mosque are calculated. Area of studied space, total height of buildings, number of openings and window to wall ratios for each mosque are stated in Table 4. Entrance facades for each mosques are also shown in Table 4 which is in direct proportion to window to wall ratios.

Table 4. Daylighting properties of case study mosques

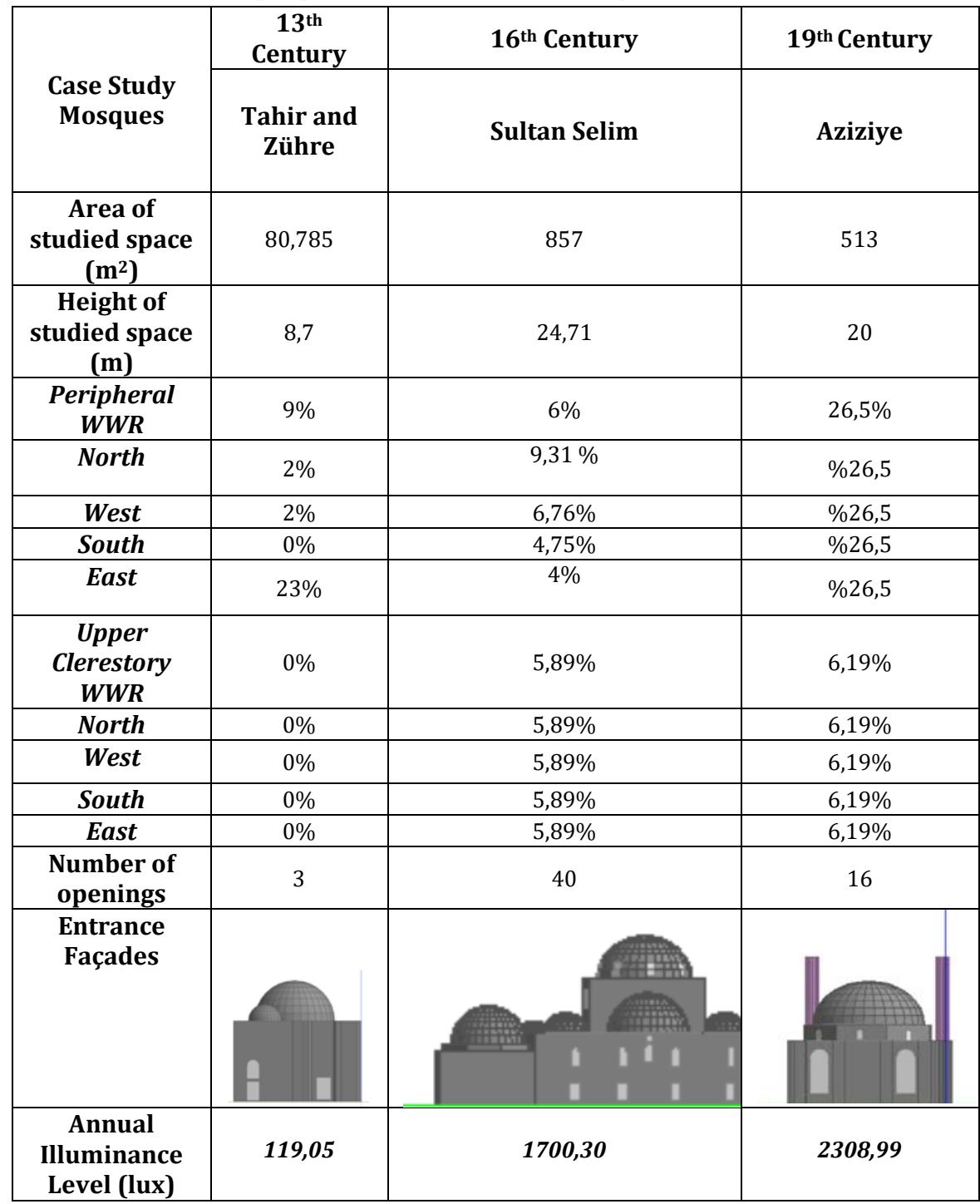


A Comparative Study on Daylight Performance of Konya Mosques Built in Anatolian Seljuk and Ottoman Period

Annual indoor daylighting performance of Tahir and Zuhre Mosque is expressed in Table 5. The illuminance levels including the equinox dates and prayer periods are illustrated in Tables 5,6,7. This study comprises a comparative study between the Tahir and Zuhre, Sultan Selim and Aziziye Mosques.

Table 5. Annual Indoor daylighting performance of Tahir and Zuhre Mosque

\begin{tabular}{|c|c|c|c|c|c|}
\hline \multicolumn{6}{|c|}{ September,23 Clear Day } \\
\hline $\begin{array}{c}\text { Illuminance } \\
\text { (Lux) }\end{array}$ & 09.00 & $\begin{array}{c}\text { Illuminance } \\
\text { (Lux) }\end{array}$ & 12.00 & $\begin{array}{l}\text { Illuminance } \\
\text { (Lux) }\end{array}$ & 17.00 \\
\hline \begin{tabular}{l|l}
$\mathbf{1}$ & 11 \\
\end{tabular} & & 7 & & 12 & \\
\hline 2 & & 5 & & 18 & \\
\hline 13 & & 13 & & 24 & \\
\hline 150 & & 53 & & 33 & \\
\hline 56 & & 36 & & 15 & \\
\hline $\begin{array}{c}\text { Average } \\
\text { Value: } 163\end{array}$ & & $\begin{array}{c}\text { Average } \\
\text { Value: } 147,5\end{array}$ & & $\begin{array}{c}\text { Average } \\
\text { Value: } 104,46\end{array}$ & \\
\hline \multicolumn{6}{|c|}{ December,21 Cloudy Intermediate Day } \\
\hline $\begin{array}{c}\text { Illuminance } \\
\text { (Lux) }\end{array}$ & 09.00 & $\begin{array}{c}\text { Illuminance } \\
\text { (Lux) }\end{array}$ & 12.00 & $\begin{array}{c}\text { Illuminance } \\
\text { (Lux) }\end{array}$ & 15.00 \\
\hline 1 & & 7 & & 19 & \\
\hline 2 & & 9 & & 7 & \\
\hline 3 & & 4 & & 6 & \\
\hline 69 & & 69 & & 41 & \\
\hline 16 & & 31 & & 21 & \\
\hline $\begin{array}{l}\text { Average } \\
\text { Value: } \\
130,65\end{array}$ & & $\begin{array}{c}\text { Average } \\
\text { Value: } \\
159,29\end{array}$ & & $\begin{array}{c}\text { Average } \\
\text { Value: } 119,05\end{array}$ & \\
\hline \multicolumn{6}{|c|}{ March,21 Clear Day } \\
\hline $\begin{array}{c}\text { Illuminance } \\
\text { (Lux) }\end{array}$ & 09.00 & $\begin{array}{c}\text { Illuminance } \\
\text { (Lux) }\end{array}$ & 12.00 & $\begin{array}{c}\begin{array}{c}\text { Illuminance } \\
\text { (Lux) }\end{array} \\
\end{array}$ & 17.00 \\
\hline 11 & & 5 & & 6 & \\
\hline 22 & & 3 & & 7 & \\
\hline 18 & & 10 & & 11 & \\
\hline 153 & & 56 & & 25 & \\
\hline 18 & & 18 & & 9 & \\
\hline $\begin{array}{l}\text { Average } \\
\text { Value: } \\
164,16\end{array}$ & & $\begin{array}{c}\text { Average } \\
\text { Value: } \\
141,25\end{array}$ & & $\begin{array}{c}\text { Average } \\
\text { Value: } 105,86\end{array}$ & \\
\hline \multicolumn{6}{|c|}{ June,21 Clear Day } \\
\hline $\begin{array}{c}\text { Illuminance } \\
\text { (Lux) }\end{array}$ & 09.00 & $\begin{array}{c}\text { Illuminance } \\
\text { (Lux) }\end{array}$ & 12.00 & $\begin{array}{c}\text { Illuminance } \\
\text { (Lux) }\end{array}$ & 17.00 \\
\hline 9 & & 13 & & 20 & \\
\hline 23 & & 7 & & 15 & \\
\hline 13 & & 16 & & 15 & \\
\hline 226 & & 70 & & 30 & \\
\hline 49 & $=$ & 30 & $-a$ & 53 & $=a$ \\
\hline $\begin{array}{c}\text { Average } \\
\text { Value: } \\
242\end{array}$ & & $\begin{array}{c}\text { Average } \\
\text { Value: } \\
212,82\end{array}$ & & $\begin{array}{c}\text { Average } \\
\text { Value: } 175,28\end{array}$ & \\
\hline
\end{tabular}


Aysil Coskuner Pamuk, İbrahim Agah Tastemir \& Umit Arpacioglu

Table 6. Annual Indoor daylighting performance of the Sultan Selim Mosque

\begin{tabular}{|c|c|c|c|c|c|c|}
\hline \multicolumn{7}{|c|}{ September,21 Clear Day } \\
\hline \multicolumn{2}{|c|}{$\begin{array}{c}\text { Illuminance } \\
\text { (Lux) }\end{array}$} & 09.00 & $\begin{array}{l}\text { Illumin. } \\
\text { (Lux) }\end{array}$ & 12.00 & $\begin{array}{c}\text { Illumin. } \\
\text { (Lux) }\end{array}$ & 17.00 \\
\hline 1 & 78 & & 64 & & 44 & \\
\hline 2 & 138 & & 110 & & 46 & \\
\hline 3 & 184 & & 245 & & 45 & \\
\hline 4 & 227 & & 302 & & 90 & \\
\hline 5 & 62 & & 870 & & 35 & \\
\hline & $\begin{array}{l}\text { age } \\
\text { ue: } \\
42\end{array}$ & & $\begin{array}{c}\text { Average } \\
\text { Value: } \\
985,06\end{array}$ & & $\begin{array}{c}\text { Average } \\
\text { Value: } \\
200,61\end{array}$ & \\
\hline & nber,2 & Cloudy Intern & ediate Da & & & \\
\hline & $\begin{array}{l}\text { nance } \\
\text { x) }\end{array}$ & 09.00 & $\begin{array}{l}\text { Illumin. } \\
\text { (Lux) }\end{array}$ & 12.00 & $\begin{array}{l}\text { Illumin. } \\
\text { (Lux) }\end{array}$ & \\
\hline 1 & 40 & & 44 & & 35 & \\
\hline 2 & 68 & & 80 & & 37 & \\
\hline 3 & 115 & & 616 & & 170 & \\
\hline 4 & 169 & & 438 & & 165 & \\
\hline 5 & 47 & $=$ & 90 & (1) & 48 & \\
\hline & $\begin{array}{l}\text { age } \\
\text { ue: } \\
70\end{array}$ & & $\begin{array}{c}\text { Average } \\
\text { Value: } \\
1362,32\end{array}$ & & $\begin{array}{c}\text { Average } \\
\text { Value: } \\
570,49\end{array}$ & \\
\hline & $2,21 \mathrm{C}$ & ar Day & & & & \\
\hline & $\begin{array}{l}\text { nance } \\
\text { x) }\end{array}$ & 09.00 & $\begin{array}{c}\text { Illumin. } \\
\text { (Lux) }\end{array}$ & 12.00 & $\begin{array}{c}\text { Illumin. } \\
\text { (Lux) }\end{array}$ & \\
\hline 1 & 50 & & 60 & & 30 & \\
\hline 2 & 118 & & 89 & & 43 & \\
\hline 3 & 230 & & 300 & & 59 & \\
\hline 4 & 290 & & 400 & & 80 & \\
\hline 5 & 88 & 0 & 93 & 0 & 61 & \\
\hline & $\begin{array}{l}\text { age } \\
\text { ue: } \\
88\end{array}$ & & $\begin{array}{c}\text { Average } \\
\text { Value: } \\
1447,34\end{array}$ & & $\begin{array}{c}\text { Average } \\
\text { Value: } \\
211,76\end{array}$ & \\
\hline & $1 \mathrm{Cle}$ & Day & & & & \\
\hline & $\begin{array}{l}\text { nance } \\
\text { x) }\end{array}$ & 09.00 & $\begin{array}{l}\text { Illumin. } \\
\text { (Lux) }\end{array}$ & 12.00 & $\begin{array}{l}\text { Illumin. } \\
\text { (Lux) }\end{array}$ & \\
\hline 1 & 60 & & 70 & & 66 & \\
\hline 2 & 152 & & 96 & & 105 & \\
\hline 3 & 164 & & 215 & 4 & 65 & \\
\hline 4 & 1211 & & 282 & & 1190 & \\
\hline 5 & 90 & - & 91 & -1 & 68 & $=$ \\
\hline & $\begin{array}{l}\text { age } \\
\text { ue: } \\
4,80\end{array}$ & & $\begin{array}{c}\text { Average } \\
\text { Value: } \\
1053,24\end{array}$ & & $\begin{array}{c}\text { Average } \\
\text { Value: } \\
262,29\end{array}$ & \\
\hline
\end{tabular}


A Comparative Study on Daylight Performance of Konya Mosques Built in Anatolian Seljuk and Ottoman Period

Table 7. Annual Indoor daylighting performance of the Aziziye Mosque

\begin{tabular}{|c|c|c|c|c|c|c|}
\hline \multicolumn{7}{|c|}{ September,23 Clear Day } \\
\hline \multicolumn{2}{|c|}{$\begin{array}{l}\text { Illuminance } \\
\text { (Lux) }\end{array}$} & 09.00 & $\begin{array}{c}\text { Illuminance } \\
\text { (Lux) }\end{array}$ & 12.00 & $\begin{array}{l}\text { Illuminance } \\
\text { (Lux) }\end{array}$ & 17.00 \\
\hline 1 & 617 & & 1220 & & 699 & \\
\hline 2 & 1308 & & 667 & & 416 & \\
\hline 3 & 2344 & & 1744 & & 421 & \\
\hline 4 & 1587 & & 1477 & & 1078 & \\
\hline 5 & 601 & & 530 & & 725 & \\
\hline \multicolumn{2}{|c|}{$\begin{array}{l}\text { Average } \\
\text { Value: } \\
2658,59\end{array}$} & & $\begin{array}{c}\text { Average } \\
\text { Value: } \\
2967,14\end{array}$ & & $\begin{array}{c}\text { Average } \\
\text { Value: } \\
1146,88\end{array}$ & \\
\hline \multicolumn{7}{|c|}{ December,21 Cloudy Intermediate Day } \\
\hline \multicolumn{2}{|c|}{$\begin{array}{l}\text { Illuminance } \\
\text { (Lux) }\end{array}$} & 09.00 & $\begin{array}{c}\text { Illuminance } \\
\text { (Lux) }\end{array}$ & 12.00 & $\begin{array}{l}\text { Illuminance } \\
\text { (Lux) }\end{array}$ & 15.00 \\
\hline 1 & 582 & & 1407 & & 814 & \\
\hline 2 & 723 & & 762 & & 450 & \\
\hline 3 & 1239 & & 2210 & & 1200 & \\
\hline 4 & 1197 & & 2200 & & 859 & \\
\hline 5 & 370 & & 730 & 4 & 376 & \\
\hline \multicolumn{2}{|c|}{$\begin{array}{l}\text { Average } \\
\text { Value: } \\
1466,27\end{array}$} & & $\begin{array}{c}\text { Average } \\
\text { Value: } \\
2920,30\end{array}$ & & $\begin{array}{c}\text { Average } \\
\text { Value: } \\
1414,46\end{array}$ & \\
\hline \multicolumn{7}{|c|}{ March,21 Clear Day } \\
\hline \multicolumn{2}{|c|}{$\begin{array}{l}\text { Illuminance } \\
\text { (Lux) }\end{array}$} & 09.00 & $\begin{array}{c}\text { Illuminance } \\
\text { (Lux) }\end{array}$ & 12.00 & $\begin{array}{c}\text { Illuminance } \\
\text { (Lux) }\end{array}$ & 15.00 \\
\hline 1 & 637 & & 1327 & & 1800 & \\
\hline 2 & 1244 & & 633 & & 604 & \\
\hline 3 & 1655 & & 1725 & & 2060 & \\
\hline 4 & 1534 & & 1923 & & 1121 & \\
\hline 5 & 610 & 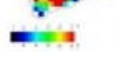 & 533 & min & 632 & \\
\hline \multicolumn{2}{|c|}{$\begin{array}{c}\text { Average } \\
\text { Value: } \\
2397,78\end{array}$} & & $\begin{array}{c}\text { Average } \\
\text { Value: } \\
3087,16\end{array}$ & & $\begin{array}{c}\text { Average } \\
\text { Value: } 2435.5\end{array}$ & \\
\hline \multicolumn{7}{|c|}{ June,21 Clear Day } \\
\hline \multicolumn{2}{|c|}{$\begin{array}{l}\text { Illuminance } \\
\text { (Lux) }\end{array}$} & 09.00 & $\begin{array}{l}\text { Illuminance } \\
\text { (Lux) }\end{array}$ & 12.00 & $\begin{array}{l}\text { Illuminance } \\
\text { (Lux) }\end{array}$ & 17.00 \\
\hline 1 & 697 & & 1134 & & 918 & \\
\hline 2 & 2365 & & 843 & & 454 & \\
\hline 3 & 1514 & & 1817 & & 1569 & \\
\hline 4 & 1861 & & 1785 & & 742 & \\
\hline 5 & 579 & -7 & 468 & -14 & 585 & $=$ \\
\hline \multicolumn{2}{|c|}{$\begin{array}{l}\text { Average } \\
\text { Value: } \\
2638,98\end{array}$} & & $\begin{array}{c}\text { Average } \\
\text { Value: } \\
2687,03\end{array}$ & & $\begin{array}{c}\text { Average } \\
\text { Value: } \\
2003,51\end{array}$ & \\
\hline
\end{tabular}

The results are also evaluated on five different spots for each equinox date by DB simulation. Results and evaluations are described below. For all three mosques, illuminance levels for each point and for each month are stated in graphical expression. 


\section{DISCUSSION}

Tahir and Zuhre Mosque has the best illuminance level at Point 4 with 60 lux in December 21. In September 23 the mosque has the best illuminance level at the same point with 80 lux. Point 4 has the best results 78 lux in March 21 and 160 lux in June 21. Point 5 also has good illuminance level according to other points. In December 21 Sultan Selim Mosque has the best illuminance level at Point 3 with 300 lux. Point 4 also has good illuminance level according to other points. the best illuminance level is at Point 5 with 322 lux and Point 4 also has good illuminance level in September 23. In March 21 Point 4 with 256 lux is the best result. Point 3 also has good illuminance level according to other points. In June 21 Sultan Selim Mosque has the best illuminance level at Point 4 with 900 lux. Point 3 also has good illuminance level. Aziziye Mosque has the best illuminance level at Point 3 with 1550 lux in December 2. Also have the best result with 1800 lux in March 21, with 1600 lux in June 21 and with 1530 lux in September 23 for the same point, Point 3. Point 4 in December 21 and June 21 And Point 1 in March 21 also has good illuminance level according to other points. At Point 3 and at Point 4 Sultan Selim and Aziziye Mosques have the same best illuminance levels in common on southern side. This is related to the mosques's locations where the two mosques stand to the south side. Orientation of the building to the south is as well based on Islamic religious belief.

In September 23 at Point 4 Sultan Selim and Aziziye Mosques have the same good illuminance levels in common. Also in June 21 Zuhre, Sultan Selim and Aziziye Mosques have the same good illuminance levels in common at the same point.

In March 23 at Point 3 Sultan Selim and Aziziye Mosques have the same good illuminance level in common. Relevant values and datas can be checked from the Tables 8,9,10 and 11 .

Despite the fact that the area and height of the studied space in numeric values and the number of openings of Sultan Selim mosque are much more than Aziziye Mosque with reference to Table 4, the rate of Aziziye Mosque's Annual and Equinox Illuminance levels for all stated points are higher. The relevant research results also show that upper windows opening built around the dome provide daylit factor which transmits daylight in southern and central location at prayer hall in Aziziye and Sultan Selim mosques. The lack of the upper windows design in Tahir and Zuhre Mosque makes the central of prayer hall with low illuminance level. This shows the important impact of upper window openings to dome design. 
A Comparative Study on Daylight Performance of Konya Mosques Built in Anatolian Seljuk and Ottoman Period

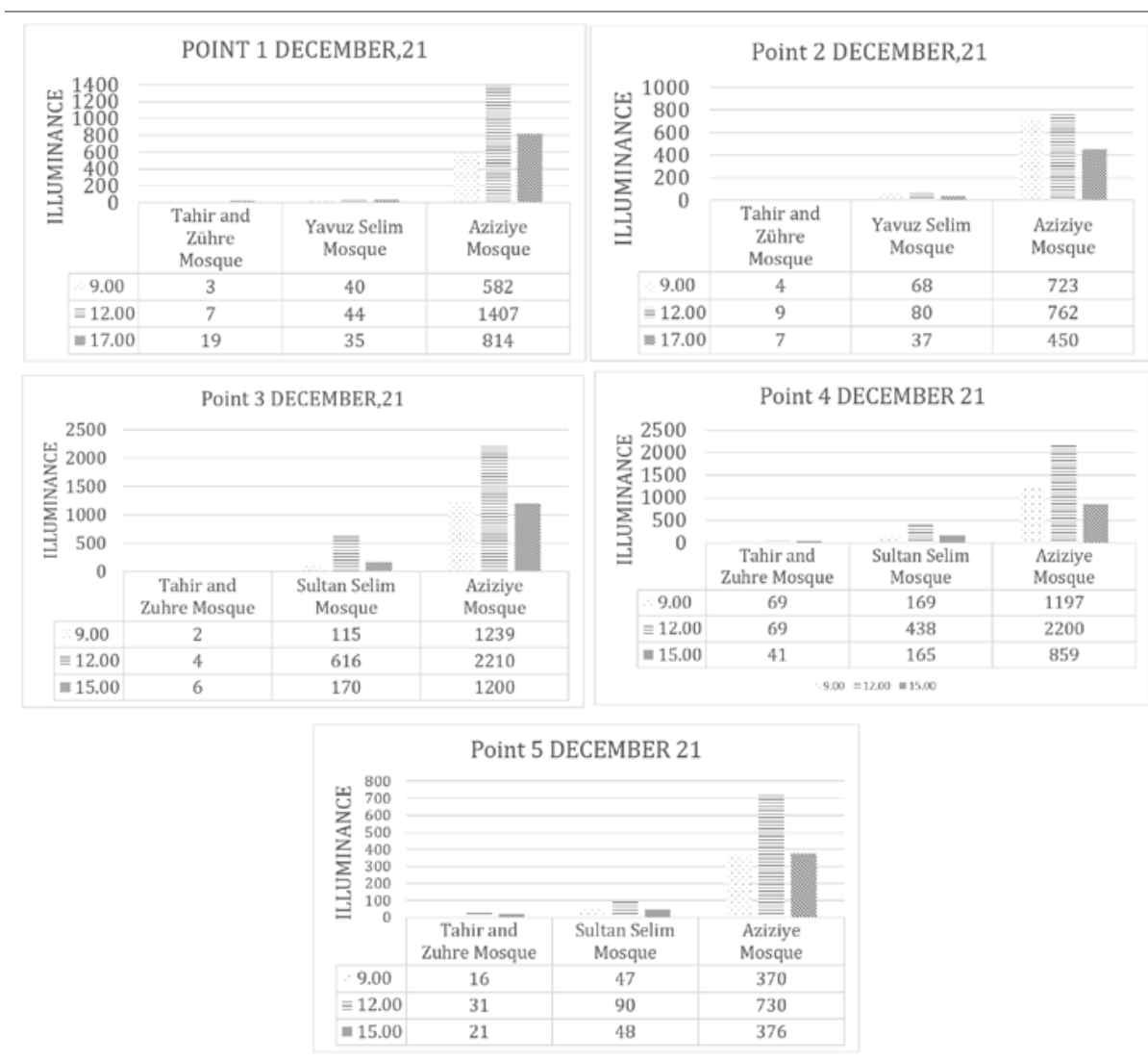

Figure 13. Illuminance levels for Points 1.2.3.4.5 (December,21)

Figure 14. Illuminance levels for Points 1.2.3.4.5 (September,23)
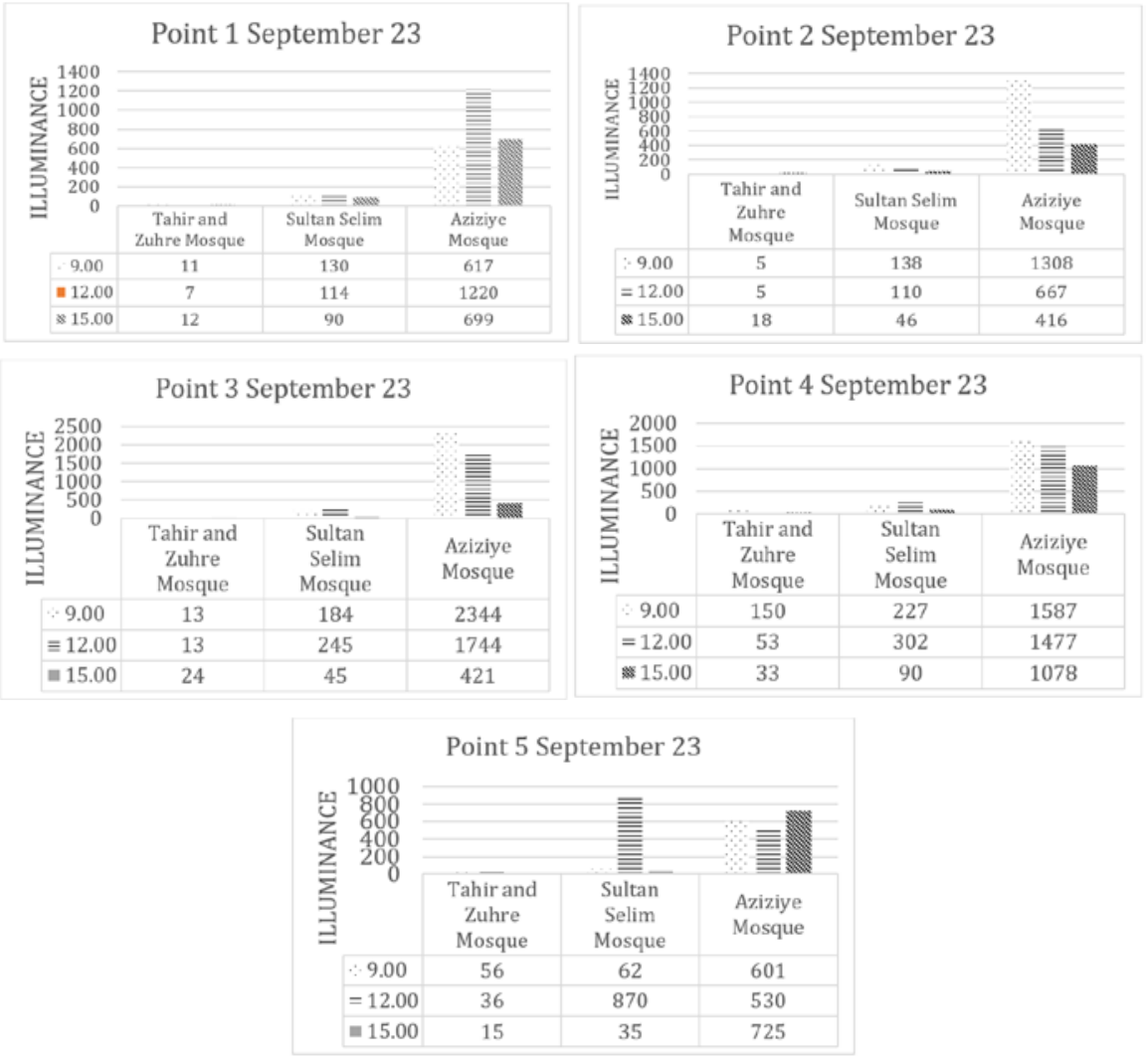

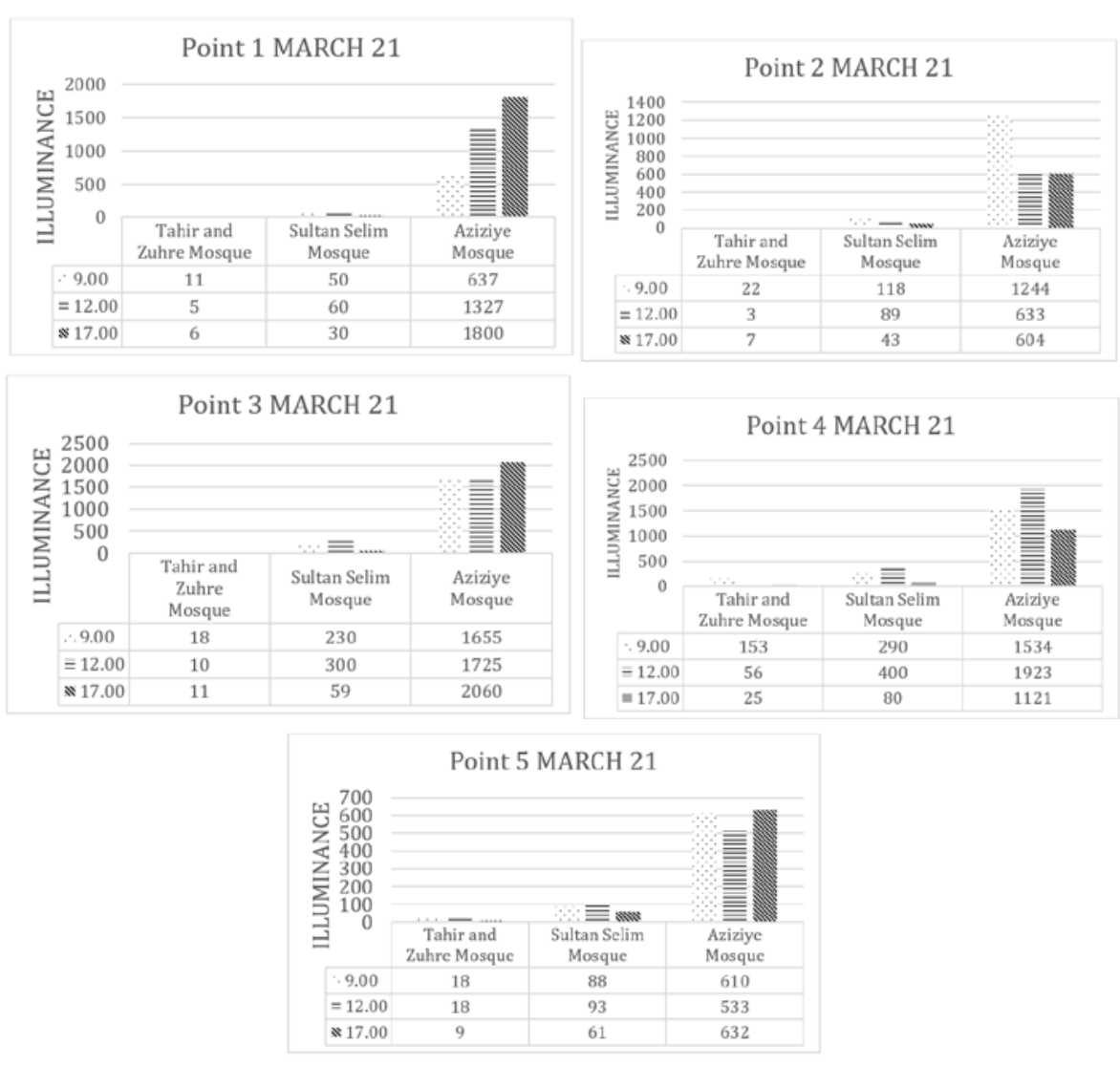

Figure 15. Illuminance levels for Points 1.2.3.4.5. (March,21)
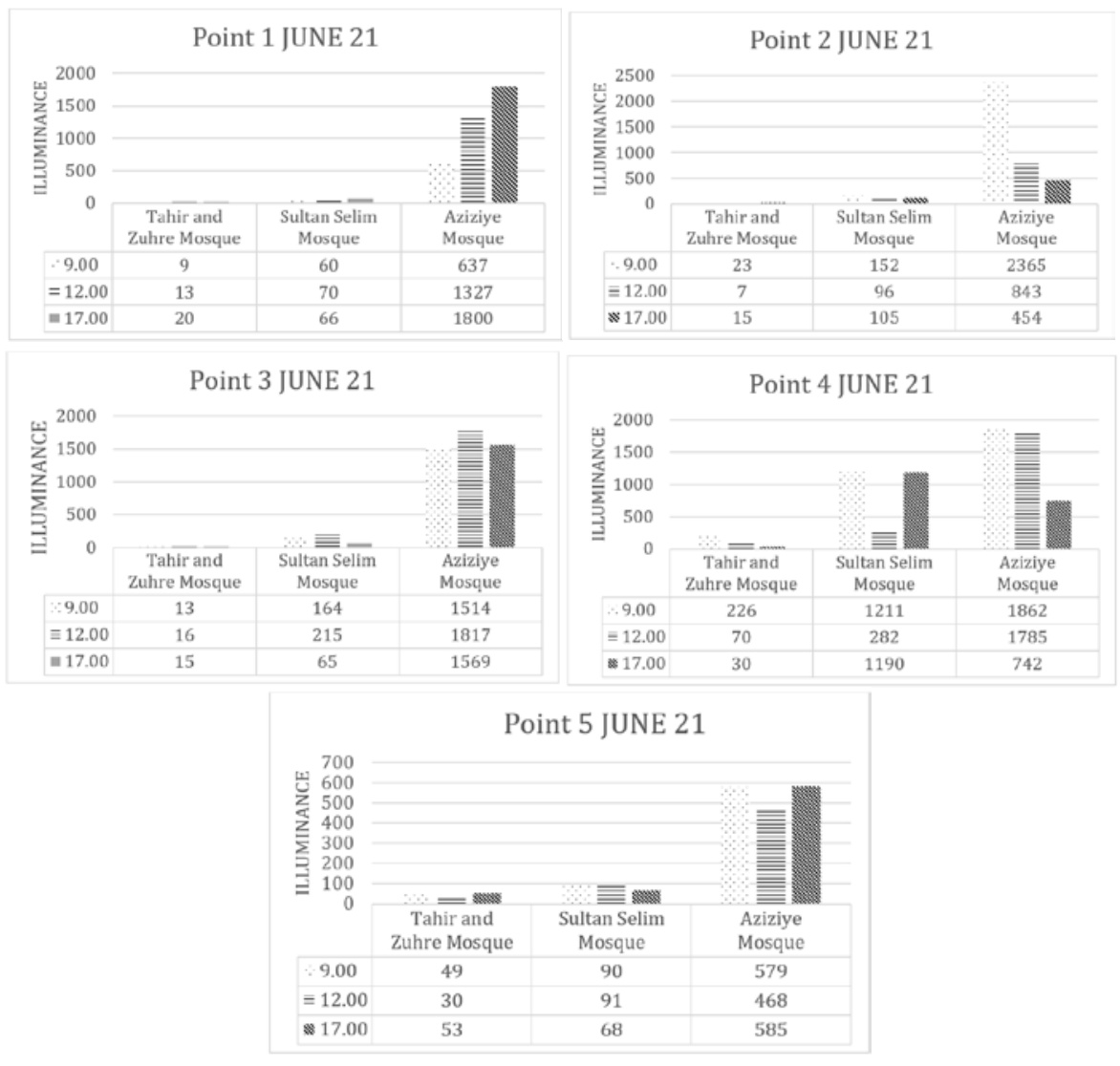

Figure 16. Illuminance levels for Points 1.2.3.4.5. (June,21) 


\section{CONCLUSION}

Daylight is used in architectural design to carry out activities in accordance with an internal space. Particularly in Islamic Architecture, daylight, where mosques were mostly related to the creation of an environment, has been used for the worshippers to fulfil their religious needs and regular visual comfort objectives. One of the most important properties of Sinan's designs was structural lightness. During and after Sinan Period Ottoman Mosque architecture continued to grab light intentionally, which yield a bright and spacious interior.

According to overall results, Sultan Selim mosque's studied space is much bigger than Aziziye mosque but its' window to wall ratio is only $6 \%$ where Aziziye Mosque's is $26.5 \%$. When we compare the two mosques' annual daylighting values Aziziye Mosque has more illuminance level and daylight in prayer halls than Sultan Selim Mosque. The research outcomes show that upper windows opening built around the dome provide daylit factor which transmits daylight in southern and central location at prayer hall in Aziziye and Sultan Selim mosques. The lack of the window design in Tahir and Zuhre Mosque makes the central of prayer hall with low illuminance level. This shows the brightness impact of the upper window openings to specialized dome design. Best illuminance level is analysed for the southern orientation for all three mosques which is directly related to Islamic religious belief and the importance of daylight in Islamic Architecture.

This study proves the fact as the building construction techniques and design criterias of the mosques from past to present improve (within the scope of Islamic mosque architecture), the illuminance level and maximized interior reflected light also increase and become much more effective. Due to WWR values, upper window features, special dome design criterias and long span distance which provide the additional daylight in, the architectural features and brightness of the mosque are much more high-lighted. Based on long span distance with the development of the bearing system provide the good illuminance levels through the windows from the walls in Aziziye Mosque even without the upper window openings. Specially Aziziye Mosque's vast interior space plan layout, without obstruction by walls and columns, helps creating a perfect lighting performance space for worshipping.

The major design criterias and construction techniques stated in this study will give inspiration to builders to design mosques which have perfect lighting performance with sacred sense of worshipping activities with a presence of divinity inside the prayer hall. It is believed that new theoretical and technical comparisons will continue to merge for the day light use in places of worship on behalf of cultural property and sustainable environment.

\section{ACKNOWLEDGEMENTS/NOTES}

The authors have no acknowledgements or other involvements in this study. 


\section{CONFLICT OF INTEREST}

No conflict of interest was declared by the authors

\section{FINANCIAL DISCLOSURE}

The authors declared that this study has received no financial support.

\section{ETHICS COMMITTEE APPROVAL}

Ethics committee approval was not required for this article.

\section{LEGAL PUBLIC/PRIVATE PERMISSIONS}

In this research, the necessary permissions were obtained from the relevant participants (individuals, institutions, and organizations) during the survey and in-situ measurements.

\section{REFERENCES}

Aljofi, E. K. (2018). The Potentiality of Domes on Provision of Daylight in Mosques. International Journal of Applied Engineering Research ISSN, 13(7), 5103-5112.

Antonakaki, T. (2007). Theodora Antonakaki. 6th International Space Syntax Symposium, 057-1/057-14.

Arel, H. Ş., \& Öner, M. (2017). Use Of Daylıght In Mosques: Meanıng And Practice In Three Different Cases. International Journal of Heritage Architecture, 1(3), 421-429. https://doi.org/10.2495/HA-V1-N3-421429

Bjørn, C. Traditional Kasbahs image. (2011). Retrieved 13 November 2020, from https://bjornfree.com/galleries

Burney, W., Hagiasophia Mosque. (n.d.). Retrieved 20 November 2020, from https://traveldigg.com/the-stunning-hagia-sophia-museumistanbul-turkey

Chepchumba, N. F. (2013). History of Daylighting: A comparative analysis across the periods. Luminous Environment, 14.

Deutsche Welle Pantheon image. (2017). Retrieved 18 January 2020, from https://www.dw.com/enitaly-romes-pantheon-to-start-charging-entryfee-for-touristsa-41747353

El-darwish, I. I., \& Gendy, R. A. E.-. (2016). The role of fenestration in promoting daylight performance. The mosques of Alexandria since the 19th century. Alexandria Engineering Journal, 55(4), 3185-3193. https://doi.org/10.1016/j.aej.2016.08.006

Eyice, S. (1991). Aziziye Camii. Içinde TDV İslâm Ansiklopedisi. İslâm Araştırmaları Merkezi. https://islamansiklopedisi.org.tr/aziziye-camii-konya

Greatest Paka Photography, Alhambra Palace image. (2012). Retrieved 20 November 2020, from https://www.flickr.com/photos/greatestpaka/7095400807/

Hareri, R., \& Alama, A. (2020). Lightıng Design In Two Mosque Typologies In The City Of Jeddah, Saudı Arabia. Islamic Heritage Architecture and Art III, 125-137. https://doi.org/10.2495/IHA200111 
A Comparative Study on Daylight Performance of Konya Mosques Built in Anatolian Seljuk and Ottoman Period

Hassan, A. S., \& Arab, Y. (2012). Lighting Analysis of Single Pendentive Dome Mosque Design in Sarajevo and Istanbul during Summer Solstice. The Arab World Geographer, 15/2, 163-179.

Horsey, R., Ummayad Mosque image (2019). Retrieved 22 November 2020, from www.adventure.com/tourism-syria-iraq

Kammoun, S., \& Saci, A. Ben. (2016). Morpho-Light In The First Great Mosques Of Tunisia, The Research Of Identity Through The Light's Form. The First International Conference On Mosque Architecture, 173-190.

Küçükdağ, Y. (2009). Sultan Selim Camii ve Külliyesi. Içinde TDV İslam Ansiklopedisi. TDV İslâm Araştırmaları Merkezi. https://islamansiklopedisi.org.tr /sultan-selim-camii-ve-kulliyesi-konya

Lec, A., \& Mohammed, S. (2015). Mosques Sinan's Mosques as case study The environmental implementation of natural lighting in congregational mosques Sinan 's Mosques as case study. 1st international engineering conference on development in civil and computer engineering applications, December 2014.

Lechner, N. (2001). Heating, cooling, lighting design methods for architects. Wiley.

Mango, C. (1986). Byzantine Architecture. Faber and Faber.

Mazloomi, M. (2010). Horizontal Distribution of Daylight Factor with Reference to Window Wall Ratio in Pendentive Dome Buildings in Tropics, Case of Kuala Lumpur. World Applied Sciences Journal, 10(10), 1247-1254.

Phillips, D. (2004). Daylighting, Natural Light in Architecture (1. baskı). Architectural Press.

Philip J.H., Eskimo, Inuit Houses image(n.d.), Lines in the Ice: Exploring the Roof of the World. McGill-Queen's University Press. https://www.canadiangeographic.ca/article/map-curator-examineshistory-arctic-exploration

Runsheng, T., Meir, I. A., \& Etzion, Y. (2003). An analysis of absorbed radiation by domed and vaulted roofs as compared with flat roofs. Energy and Buildings, 35, 539-548.

Shahani, M. (2018). Sheikh Lotfollah Mosque: A Story of Daylight in Sequential Spaces. Space and Culture, 1, 1-18. https://doi.org/10.1177/1206331218782406

Stein, B., \& Reynolds, J. (2000). Mechanical and Electrical Equipment for Buildings (9. baskı). Wiley.

Tørrissen, B. C. (2011). Traditional Kasbahs. Retrieved 22 March 2020, https://bjornfree.com/travel/galleries/

Yavaș, A. (2008). Konya Sahip Ata (Tahir ile Zühre) Mescidi Alptekin. Atatürk Üniversitesi Güzel Sanatlar Enstitüsü Dergisi, 20, 161-178. 


\section{Resume}

Ayşll Coşkuner Pamuk receives her B.Arch. from Mimar Sinan University major of Architecture Department and M.Arch. from Mimar Sinan University the Institute of Science and Technology, Building Physics and Materials Department in 2018. She currently works as a researcher on building materials and building physics in Istanbul Sabahattin Zaim University, Department of Architecture. She is a PhD candidate in IZU, Department of Architecture.

Ibrahim Agah Taştemir receives his bachelor's degree at Istanbul Sabahattin Zaim University, Department of Architecture in 2017. He completed his masters at Mimar Sinan Fine Arts Universit, Building Physics and Materials Department in 2020. His research interests are building physics, energy efficient building design, thermal comfort, daylight in buildings. Currently he is working as Research Assistant at Istanbul Sabahattin Zaim University, Department of Interior Architecture, he is PhD candidate at Department of Architecture.

Born in 1976, in Istanbul. Umit Arpacıoğlu receives his bachelor's degree at Mimar Sinan Fine Arts University at 2001, on the same year he began his career as a research asisstant in the Department of Architecture at MSFAU. He completed his masters and PhD thesis at the Institute of Science and Technology, Building Physics and Material Department. Since 2017, he continues his career as an associate professor doctor at MSFAU. 